\title{
Faktor-faktor yang Mempengaruhi Profitabilitas Bank Syariah Indonesia dan Malaysia
}

\author{
Ike Dwi Astuti ${ }^{1 *}$, Nur Kabib ${ }^{2)}$ \\ ${ }^{1,2}$ Fakultas Ekonomi dan Bisnis Islam, Institut Agama Islam Negeri Salatiga \\ *Email korespondensi: ikedwiastuti99@gmail.com
}

One of the benchmarks for state progress in banking which affects economic activity (Khasanah, 2016). This study aims to determine the factors that influence profitability included CAR, BOPO, FDR, on ROA with NPF as a moderating variable for Indonesian and Malaysian Islamic banking listed in the Financial Services Authority (OJK) and Bank Negara Malaysia (BNM) for the 2014-2019 period. This type of quantitative research with secondary data is in the form of panel data. The sample includes 11 Indonesian Islamic banks and 7 Malaysian Islamic banks. The collection method is to access the annual report on the bank's website. Multiple Linear Regression analysis tool with the Eviews 10 Version application. The analysis used the Descriptive Statistical Test, Stationarity Test, and Multiple Linear Regression Test. The test results include: 1) CAR is not significant to ROA; 2) BOPO is not significant to ROA; 3) FDR is not significant to ROA; 4) CAR with NPF as a moderating variable has a positive and significant effect on ROA; 5) BOPO with NPF as a moderating variable has a negative and significant effect on ROA; 6) FDR with NPF as a moderating variable has a negative and significant effect on ROA.

Keywords: ROA, CAR, BOPO, FDR, NPF

Saran sitasi: Astuti, I. D., \& Kabib, N. (2021). Faktor-faktor yang Mempengaruhi Profitabilitas Bank Syariah Indonesia dan Malaysia. Jurnal Ilmiah Ekonomi Islam, 7(02), 1053-1067. doi:http://dx.doi.org/10.29040/jiei.v7i2.2534

DOI: http://dx.doi.org/10.29040/jiei.v7i2.2534

\section{PENDAHULUAN}

Tolok ukur kemajuan negara salah satunya adalah perbankan yang memiliki pengaruh terhadap kegiatan perekonomian. Perkembangan dan kemajuan ekonomi dialami oleh industri perbankan. Berdasarkan prinsip operasional, perbankan meliputi perbankan konvensional dan syariah (Khasanah, 2016). Perbankan mempunyai peran penting dalam aktifitas perekonomian. Bank berperan menghimpun serta menyalurkan dana yang diperoleh dari masyarakat menuju peningkatan taraf hidup rakyat secara efektif dan efisien (Wiwoho, 2014). Kegiatan utama lembaga keuangan bank meliputi tabungan, deposito, dan simpanan giro (Arinta, 2016). Selain itu, perbankan juga berperan strategis untuk menunjang pembangunan ekonomi nasional. Pemerintah perlu menyiapkan semua sektor salah satunya perbankan untuk menunjang pembangunan ekonomi nasional (Sengkey et al., 2018).
Kegiatan operasional perbankan syariah sesuai Al-Qur`an dan Hadits (Kabib et al., 2021). Perbankan syariah mempunyai kesempatan besar untuk menguatkan perekonomian negara karena mampu bertahan dan lebih mandiri dalam menghadapi gejolak moneter yang berasal dari dalam maupun luar negeri (Marimin \& Romdhoni, 2017). Berdasarkan data dari Global Islamic Finance Report (GIFR) tahun 2019 bahwa Indonesia memperoleh skor 81,93 yang mana mengalami peningkatan dari sebelumnya 57,8. Sedangkan Malaysia memperoleh skor 81,05. Pertumbuhan ekonomi syariah di Indonesia dan Malaysia semakin menunjukkan perkembangan setiap tahunnya. Penduduk mayoritas muslim menjadi penyebab salah satunya (cnnindonesia.com, 2019).

Perbankan syariah pertama di Indonesia tahun 1991 adalah Bank Muamalat Indonesia, beroperasi dengan dukungan Majelis Ulama Indonesia, pemerintah, dan sebagian pengusaha muslim, seperti 


\section{Jurnal Ilmiah Ekonomi Islam, 7(02), 2021, 1054}

Ikatan Cendikiawan Muslim di Indonesia tahun 1992. Perseroan mencatat Kerugian Bank Muamalat tahun 1998 akibat dampak krisis mencapai Rp 105 miliar. Bank Muamalat berupaya menemukan pemodal potensial yakni memperoleh suntikan dana dari Islamic Development Bank, Arab Saudi. Tahun 19992002 kembali bangkit dan memperoleh laba (Thoin,2019); (Munifa et al., 2019). UU No. 21 tahun 2008 Perbankan Syariah yaitu semua hal mengenai Bank Syariah serta Unit Usaha Syariah, seperti kegiatan usaha, kelembagaan, serta pelaksanaan kegiatan usaha.

Perbankan syariah di Malaysia pertama kali yaitu tahun 1980 diperkenalkan berdasarkan inisiatif Perdana Menteri (Mahathir Muhammad) saat secara resmi Malaysia membuat Undang-Undang Perbankan Syariah (1983) serta UU Takaful (1984). Bank syariah menerapkan konsep secara lengkap sebagai perusahaan umum pada tahun 1983 (Ghozali, 2020). Pada 1 Maret 1983 Bank Islam Berhad merupakan bank yang pertama kali didirikan dengan menawarkan layanan dan produk perbankan syariah (Abdullah et al., 2019).

Indonesia dan Malaysia sebagai negara mayoritas muslim yang mempunyai potensi untuk mengembangkan perbankan syariah. Jumlah muslim di negara indonesia sebanyak 231.000.000 jiwa. Sedangkan di Malaysia sebanyak 16.318.355 jiwa (id.wikipedia.org). Berdasarkan Global Islamic Economy Report, peringkat tata kelola perusahaan, awareness, finansial, dan sosial keuangan syariah Malaysia sudah lebih maju dari Indonesia. Berikut gambar pemegang aset syariah terbesar:

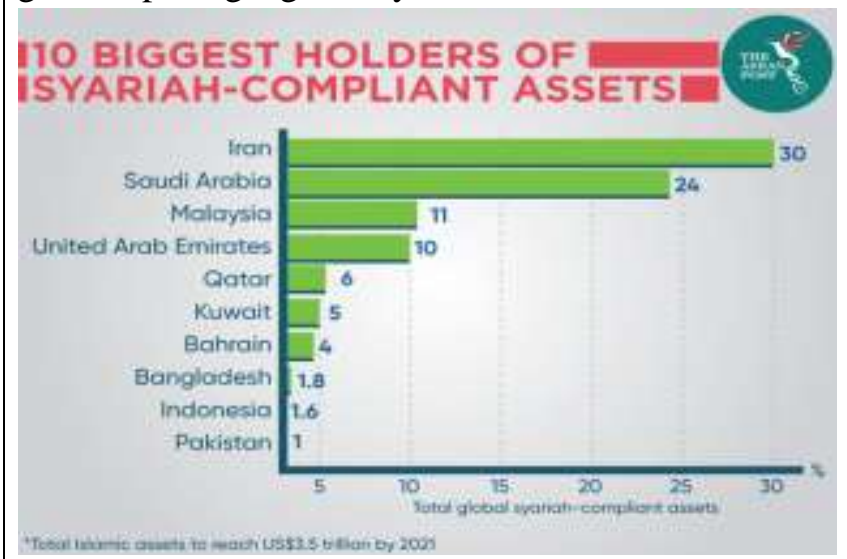

\section{Gambar 1.1 10 Top Biggest Holders of Syariah- Compliant Assets}

Sumber: Union of Arab Banks, Thomson Reuters

Berkembangnya perbankan syariah di Indonesia maupun Malaysia perlu dibarengi dengan naiknya profitabilitas, hal tersebut mengakibatkan kepercayaan masyarakat terhadap bank menjadi lebih baik. Profitabilitas sebagai cerminan memperoleh laba bank dari kepemilikan pengelolaan (Rifai et al., 2013). Penelitian ini variabel profitabilitasnya diukur dengan ROA (Return On Assets). Keunggulan rasio ROA sebagai pengukuran komprehensif mempengaruhi laporan keuangan, mudah dihitung dan dipahami, serta sebagian besar dapat diterapkan di setiap unit organisasi profitabilitas (Arnova, 2016). Berikut daftar perkembangan profitabilitas bank syariah Indonesia dan Malaysia:

Tabel 1.1 Perkembangan Rasio Profitabilitas

\begin{tabular}{|c|c|c|}
\hline \multirow{2}{*}{ Tahun } & \multicolumn{2}{|c|}{ Perkembangan rasio profitabilitas } \\
\cline { 2 - 3 } & Indonesia & Malaysia \\
\hline 2014 & $0.79 \%$ & $1.2 \%$ \\
\hline 2015 & $0.84 \%$ & $1.0 \%$ \\
\hline 2016 & $0.63 \%$ & $1.0 \%$ \\
\hline 2017 & $0.63 \%$ & $1.1 \%$ \\
\hline 2018 & $1.28 \%$ & $1.1 \%$ \\
\hline 2019 & $1.73 \%$ & $1.2 \%$ \\
\hline
\end{tabular}

Berdasarkan tabel 1.1 profitabilitas mengalami stagnansi dan kenaikan. Rasio ROA perbankan syariah Indonesia dan Malaysia berkembang hampir setiap tahunnya. Perkembangan ROA memiliki arti efisiennya pengelolaan aset perbankan. Pentingnya ROA diteliti adalah untuk menjaga keberlanjutan perusahaan dan para stake holder (Sengkey et al., 2018).

Variabel ROA dipengaruhi beberapa hal seperti: Capital Adequacy Ratio (CAR), Efisiensi Operasional menggunakan rasio biaya operasional terhadap pendapatan operasional (BOPO), Financing to Deposit Ratio (FDR), dan Net Performing Financing (NPF). CAR sebagai rasio untuk mengetahui banyaknya aktiva berisiko suatu bank. Aktiva tertimbang menurut risiko (ATMR) yaitu $8 \%$ perlu dipertahankan sebagai bentuk kewajiban dalan menyediakan modal minimum bank. Pengupayaan penyediaan modal tersebut karena dalam menambah kegiatan yang membutuhkan aktiva perlu penambahan modal (Tambuwun \& Sondakh, 2015). Hasil penelitian C. Zelin (2018), Dedy dan Addien (2017), Desi (2016), dan Siti (2015) CAR berpengaruh positif signifikan terhadap ROA. Namun berbeda Annisa (2018) bahwa CAR berpengaruh negatif terhadap ROA. Serta penelitian Retna (2017) CAR tidak berpengaruh signifikan terhadap ROA.

Rasio BOPO untuk mengetahui kemampuan dalam mengendalikan biaya operasional terhadap pendapatan operasional bank (Hartini, 2016). 


\section{Jurnal Ilmiah Ekonomi Islam, 7(02), 2021, 1055}

Pengelolaan biaya operasional bank semakin efisien apabila rasio BOPO kecil. Penelitian Dyah (2019), Yani (2017), Monica (2017), serta Ayu (2016) BOPO memiliki pengaruh negatif terhadap ROA. Sedangkan penelitian Siti (2018) BOPO tidak memiliki pengaruh terhadap ROA.

Variabel (FDR) pengendaliannya masih menjadi masalah dilematik dalam dunia perbankan. Tingginya tingkat rasio FDR sebagai indikator bank gagal dalam menjalankan bisnis. Sebaliknya rendahnya FDR menunjukkan bank memiliki likuiditas baik, namun tidak mampu menyalurkan pembiayaan secara optimal, hal tersebut menyebabkan tingkat profitabilitas turun. FDR bertujuan sebagai pengukur kesehatan kegiatan atau operasi bank (Almunawwaroh \& Marliana, 2018). Hasil penelitian Medina dan Rina (2018), Muhammad dan Salamah (2017), serta Ningsukma dan Haqiqi menyatakan FDR memiliki pengaruh negatif terhadap ROA. Namun Kustiyani (2019) FDR memiliki pengaruh positif dan signifikan. Serta Uswatun (2017) FDR tidak berpengaruh terhadap ROA.

Listin dan Rohmawati (2015), Risiko yang sering dihadapi bank umum syariah sebagai lembaga intermediasi seperti halnya yang biasa dihadapi bank konvensional yakni risiko NPF. NPF digunakan untuk mengetahui pembiayaan yang bermasalah terhadap total pembiayaan yang disalurkan bank. Variabel moderasi penelitian ini menggunakan NPF yang dipengaruhi oleh CAR, BOPO, dan FDR terhadap ROA. Oleh karena itu, peneliti memiliki ketertarikan untuk meneliti profitabilitas perbankan syariah Indonesia dan Malaysia yang berjudul "Faktor-faktor yang Mempengaruhi Profitabilitas Bank Syariah Indonesia dan Malaysia".

Beberapa Tinjauan Pustaka yang digunakan dalam pengembangan hipotesis

a. Return On Assets (ROA)

Rasio profitabilitas digunakan sebagai pengukur tingkat laba atau keuntungan dari aktivitas. Penelitian ini dalam mengukur rasio profitabilitas menggunakan ROA. Tujuan rasio ini untuk membandingkan antara laba dengan total asset suatu bank dan mengetahuin tingkat efisiensi dari pengelolaan asset suatu perusahaan (Sambelay \& Rate, 2017). Penelitian Annisa (2018) bahwa penelitian ROA lebih diutamakan karena menunjukkan kemampuan bank dalam mengelola asset dari masyarakat. Surat Edaran Bank Indonesia No. 30/3/UPPB pada 30 April 1997 serta Surat Keputusan Direksi BI No. 30/12/KEP/DIR tentang penilaian kesehatan bank diatas 1,215\%. Berdasarkan ketetapan dari Bank Indonesia bahwa dalam menghitung ROA dengan rumus :

$$
R O A=\frac{\text { Laba Bersih }}{\text { Total Aset }} X 100 \%
$$

b. Capital Adequacy Ratio (CAR)

Permodalan digunakan untuk mengetahui besarnya jumlah modal yang dimiliki bank. Modal merupakan cerminan besarnya sumber dana dalam pembiayaan operasional bank. Penelitian ini menggunakan rasio permodalan yang diukur dengan CAR. Rasio ini yaitu cukupnya modal sebagai pertahanan modal yang meliputi kemampuan manajemen dalam identifikasi, pengawasan, serta kontrol risiko sebagai pengaruh terhadap modal bank. Ketentuan BSI (Bank for International Setlement) yakni rasio pemenuhan kebutuhan Modal Minimal Bank sebanyak 8\% (Zulifiah \& Susilowibowo, 2014). Secara sistematis, penghitungan rasio CAR menggunakan rumus :

$$
\mathrm{CAR}=\frac{\text { Modal Bank }}{\mathrm{ATMR}} \times 100 \%
$$

c. Belanja Operasional terhadap Pendapatan Operasional (BOPO)

Biaya Operasional sebagai rasio pembanding beban operasional dengan pendapatan operasional. Mengetahui tingkat efisiensi dan kemampuan menjalankan kegiatan operasional bank menggunakan BOPO. Ketetapan Bank Indonesia beradasarkan SE No. 6/73/INTERN 24 Desember 2004 bisa ditolerir perbankan maksimal 96\%. Bank dinilai efisien ketika mengeluarkan biaya operasional dengan rasio BOPO semakin kecil. Keadaan tersebut memungkinkan kondisi bermasalah dalam bank semakin kecil (Wibisono, 2017). Rumus penghitungan BOPO adalah:

$$
\text { BOPO }=\frac{\text { Biaya Operasional }}{\text { Pendapatan Operasional }} \times 100 \%
$$

\section{d. Financing to Deposit Ratio (FDR)}

FDR sebagai rasio yang digunakan sebagai pengukur kemampuan penyaluran dana bank terhadap pihak yang memerlukan modal. Tingginya tingkat aset perbankan menyebabkan semakin tinggi FDR sehingga kerawanan perbankan semakin tinggi. FDR sebagai cerminan kemampuan membayar kembali penarikan dana oleh deposan terhadap andalan kredit yang diberikan untuk sumber likuiditas. Atau dengan artian cerminan pemberian kredit terhadap nasabah bisa mengimbangi kewajiban bank dengan penuhi deposan yang berkeinginan mengambil kembali 
uangnya dimana pihak bank menggunakannya sebagai pemberian kredit (Pravasanti, 2018). Indikasi tingginya rasio FDR mengakibatkan semakin rendahnya bank dalam likuiditas. Penyebabnya adalah dana untuk membiayai kredit lebih besar. Rasio FDR menunjukkan kemampuan dan kerawanan suatu bank. Batas aman rasio FDR adalah $85 \%$ - 100\% (Wibisono, 2017). Surat Edaran BI No. 3/30 DPNP tanggal 14 bahwa jumlah pinjaman diberikan terhadap jumlah dana pihak ke tiga. Rasio FDR dihitung menggunakan rumus:

$$
\text { FDR }=\frac{\text { Jumlah dana yang diberikan }}{\text { Total dana pihak ketiga }} X 100 \%
$$

e. Non Performing Financing (NPF)

Rasio NPF merupakan cerminan pembiayaan bermasalah perbankan. NPF memberikan dampak pada profitabilitas bank. Tingkat NPF yang tinggi menjadikan pembiayaan menjadi rendah. Ketika tingkat pembiayaan rendah, mengakibatkan Profitabilitas akan rendah (Munir, 2018). Berdasarkan Surat Edaran BI No. 3/30 DPNP tanggal 14 Desember 2001, pengukuran NPF dengan membandingkan pembiayaan bermasalah terhadap total pembiayaan. NPF dihitung menggunakan rumus:

$$
\mathrm{NPF}=\frac{\text { Pembiayaan Bermasalah }}{\text { Total Pembiayaan }} \times 100 \%
$$

\section{METODE PENELITIAN}

\section{Jenis Penelitian}

Jenis penelitian adalah kuantitatif yaitu pengumpulan data berbentuk angka, kemudian diolah serta dianalisis guna memperoleh informasi ilmiah dari angka-angka tersebut (Mulyadi, 2013). Penelitian menggunakan data sekunder yaitu pemerolehan data mengacu pada informasi yang tersusun kemudian dipublikasikan oleh instatnsi terkait. Data yang digunakan adalah data panel yakni gabungan data cross section dan time series. Variabel ROA sebagai cross section dan time series meliputi CAR, BOPO, FDR, serta NPF.

Penelitian ini dimaksudkan guna meneliti pengaruh CAR, BOPO, dan FDR terhadap ROA dengan NPF sebagai variabel moderasi pada Perbankan Syariah Indonesia dan Malaysia tahun 2014-2019. Penelitian dilaksanakan di Bank Umum Syariah Indonesia dan Malaysia yang memenuhi kriteria untuk penelitian ini. Data penelitian menggunakan annual report yang sudah dipublikasikan pada website resmi perbankan Indonesia dan Malaysia

\section{Populasi dan Sampel}

Generalisasi dari subyek ataupun obyek yang memiliki karakteristik atau kualitas yang dibutuhkan peneliti dengan tujuan dipelajari kemudian menarik kesimpulan disebut sebagai populasi (Handayani \& Budianingrum, 2011). Populasi dalam penelitian ini yaitu Bank Syariah yang terdaftar di OJK serta BNM periode 2014-2019.

Sampel merupakan sebagian dari jumlah serta karakteristik populasi. Penelitian menggunakan purposive sampling yakni dalam penentuan sampel dipilih didasarkan atas karakteristik anggota sampel yang ditentukan untuk maksud dan tujuan tertentu (Yuliana, 2012). Adapun kriteria dan pertimbanganpertimbangan penentuan sampel pada penelitian ini meliputi:

a. Perbankan syariah Indonesia serta Malaysia yang terdapat dalam daftar OJK dan BNM.

b. Perbankan syariah meliputi bank umum syariah yang kepemilikan lokal bukan asing.

c. Perbankan syariah secara konsisten mempublikasikan annual report tahun 2014-2019.

d. Perbankan syariah yang mempunyai data diperlukan dalam penelitian tahun 2014-2019.

\begin{tabular}{|c|c|c|c|}
\hline No & Kriteria Sampel & Indonesia & Malaysia \\
\hline 1. & $\begin{array}{l}\text { Perbankan syariah yang } \\
\text { terdapat dalam daftar } \\
\text { OJK dan BNM }\end{array}$ & 14 & 16 \\
\hline 2. & $\begin{array}{l}\text { Kepemilikan bank } \\
\text { syariah lokal bukan } \\
\text { asing }\end{array}$ & 13 & 11 \\
\hline 3. & $\begin{array}{l}\text { Bank syariah yang } \\
\text { mempublikasikan } \\
\text { annual report tahun } \\
\text { 2014-2019 }\end{array}$ & 12 & 10 \\
\hline 4. & $\begin{array}{l}\text { Perbankan syariah yang } \\
\text { mempunyai data yang } \\
\text { diperlukan } \\
\text { penelitian }\end{array}$ & 11 & 7 \\
\hline
\end{tabular}

Tabel 3.1 Kriteria Pemilihan Sampel Penelitian

Banyaknya sampel yang memenuhi kriteria yaitu 11 bank syariah Indonesia dan 7 Bank syariah Malaysia. Tabel berikut menunjukkan sampel penelitian: 


\section{Jurnal Ilmiah Ekonomi Islam, 7(02), 2021, 1057}

Tabel 3.2 Daftar Bank Syariah sebagai Sampel Penelitian

\begin{tabular}{|c|c|c|c|}
\hline No & Indonesia & No & Malaysia \\
\hline 1. & Bank BCA Syariah & 11. & $\begin{array}{l}\text { Maybank Islamic } \\
\text { Berhad }\end{array}$ \\
\hline 2. & $\begin{array}{l}\text { Bank Jabar \& } \\
\text { Banten Syariah }\end{array}$ & 12. & $\begin{array}{l}\text { Am Islmaic Bank } \\
\text { Berhad }\end{array}$ \\
\hline 3. & BNI Syariah & 13. & $\begin{array}{l}\text { Bank Islam } \\
\text { Malaysia Berhad }\end{array}$ \\
\hline 4. & $\begin{array}{l}\text { Bank Rakyat } \\
\text { Indonesia Syariah }\end{array}$ & 14. & $\begin{array}{l}\text { CIMB Islamic Bank } \\
\text { Berhad }\end{array}$ \\
\hline 5. & $\begin{array}{l}\text { Bank Victoria } \\
\text { Syariah }\end{array}$ & 15. & $\begin{array}{l}\text { Hong Leong Islamic } \\
\text { Bank Berhad }\end{array}$ \\
\hline 6. & $\begin{array}{l}\text { Bank Bukopin } \\
\text { Syariah }\end{array}$ & 16. & $\begin{array}{l}\text { Affin Islamic Bank } \\
\text { Berhad }\end{array}$ \\
\hline 7. & $\begin{array}{l}\text { Bank Mega } \\
\text { Syariah }\end{array}$ & 17. & $\begin{array}{l}\text { RHB Islamic Bank } \\
\text { Berhad }\end{array}$ \\
\hline 8. & $\begin{array}{l}\text { Bank Syariah } \\
\text { Mandiri }\end{array}$ & & \\
\hline 9. & $\begin{array}{l}\text { Bank Muamalat } \\
\text { Indonesia }\end{array}$ & & \\
\hline 10. & $\begin{array}{l}\text { Bank Panin Dubai } \\
\text { Syariah }\end{array}$ & & \\
\hline 11. & $\begin{array}{l}\text { Bank BTPN } \\
\text { Syariah }\end{array}$ & & \\
\hline
\end{tabular}

\section{Teknik Pengumpulan Data}

Teknik pengumpulan data penelitian berupa observasi tidak langsung, yakni dalam pengumpulan dokumen-dokumen annual report perbankan syariah Indonesia dan Malaysia periode 2014-2019. Penelitian ini menggunakan data sekunder yaitu data yang didapatkan peneliti dari sumber yang sudah tersedia (Novalia \& Nindito, 2016). Data penelitian ini didapat pada website resmi perbankan Indonesia dan Malaysia. Annual report tersebut kemudian diolah untuk menghasilkan hipotesis. Sumber lain penelitian ini meliputi jurnal, artikel, buku, laporan penelitian, serta perangkat lainnya yang berhubungan dengan penelitian. Hal tersebut bertujuan penulis terbantu dalam memecahkan masalah yang diteliti, kemudian hasilnya digunakan untuk bahan pertimbangan. Penelitian membutuhkan adanya variabel. Variabel penelitian sebagai atribut, konstruksi, nilai seseorang, kegiatan maupun obyek ditetapkan oleh peneliti yang mempunyai variasi tertentu guna dipelajari, dicari informasinya, serta diambil kesimpulannya (Komasari \& Helmi, 2000). Definis operasional variabel meliputi:

\section{Teknik Analisis}

Teknik analisis data merupakan cara mengolah pengumpulan data sehinga bisa menghasilkan olahan data. Tujuan teknik analisis adalah sebagai penjawab dari permasalahan yang sudah dirumuskan. Pentingnya profitabilitas suatu bank serta sebagai pelaksana prinsip kehati-hatian dan tidak merugikan masyarakat. Analisis deskriptif kuantitatif dan regresi dalam penelitian ini sebagai pengukur pengaruh CAR, BOPO, dan NPF terhadap ROA dengan NPF sebagai Variabel moderasi pada perbankan syariah Indonesia dan Malaysia. Rasio CAR, BOPO, FDR dengan dimoderasi NPF berpengaruh terhadap ROA. ROA (Profitabilitas) perbankan dinilai baik apabila bisa meningkatkan kepercayaan masyarakat dengan menyimpan dananya ataupun melakukan transaksi yang lain (Siagian et al., 2018). Analisis regresi diolah memakai data panel yaitu perpaduan data cross section dan time series. Model regresi data panel dalam penelitian yakni sebagai berikut:

$\mathrm{Y}=\alpha+\beta 1 \mathrm{CAR}+\beta 2 \mathrm{BOPO}+\beta 3 \mathrm{FDR}+\beta 4 \mathrm{NPF}+$ $\beta 5 \mathrm{NPFCAR}+\beta 6 \mathrm{NPFBOPO}+\beta 7 \mathrm{NPFFDR}+\mathrm{e}$ Keterangan:

$\mathrm{Y}=$ Profitabilitas (ROA)

$\alpha=$ Konstanta

$\mathrm{e}=$ Error

\section{a. Uji Stasioneritas}

Penelitian menggunakan Uji Levin, Lin \& Chu. Data dinilai stasioner apabila waktu rata-rata variannya bersifat konstan dan kovarian antar dua data runtut waktu dari kelambanan dua tahun (Anam et al., 2021). Keputusan uji stasioner diambil apabila nilai probabilitas $<0,05$ memiliki arti bahwa data memiliki sifat stasioner (Ardana, 2018).

\section{b. Penentuan Model Estimasi}

Banyaknya variabel penjelas memungkinkan semakin kompleks estimasi parameternya. Perlu beberapa metode dalam melakukan estimasi parameternya, meliputi:

\section{1) Common Effect Model (CEM)}

Penggabungan seluruh data dalam metode Common Effect Model (CEM) tidak memperhatikan waktu serta tempat penelitian. Asumsinya adalah perilaku data antar unit cross section dari berbagai periode yaitu sama. Masing-masing variabel memiliki nilai intersep sama, seperti halnya slop koefisien seluruh unit time series serta cross section. 


\section{Jurnal Ilmiah Ekonomi Islam, 7(02), 2021, 1058}

Sebagai upaya untuk mengestimasi parameter common effect model maka bisa menggunakan Ordinary Least Square (OLS) (Wulandari, 2017).

Persamaan regresi Common effect model dengan $n$ variabel dituliskan :

$$
\text { Yit }=\text { Xitßit }+ \text { eit }
$$

Keterangan:

Yit : Penelitian dari unit ke-i serta diamati periode ke-t (yaitu variabel dependen data panel).

Xit : Variabel independen unit ke-i dan diamati periode ke-t disini asumsi Xit sebagai variabel konstanta.

eit : Komponen error mempunyai harga mean 0 dan variansi homogen dalam waktu serta independen dengan Xit.

2) Fixed Effect Model (FEM)

Teknik estimasi data panel dan variabel dummy dengan tujuan memperoleh intercept disebut sebagai Fixed Effect Model (FEM). Intercept diantara bank syariah, terjadinya perbedaan intercept karena adanya perbedaan manajerial, budaya kerja serta insentif. Model ini diasumsikan koefisien regresi tetap diantara perbankan serta waktu (Wulandari, 2017).

Variabel dummy pendekatannya biasa disebut least square dummy variabel (LSDV). Berikut model regresi FEM:

Dimana:

$$
\text { Yit } \quad=\operatorname{Xit} \beta+\mathrm{Ci}+\ldots .+ \text { git }
$$

Xit : Variabel independen unit ke-i dan diamati pada periode ke-t dengan asumsi Xit sebagai variabel konstanta

$\mathrm{Ci}$ : Variabel dummy

\section{3) Random Effect Model (REM)}

Estimasi REM yaitu efek individu yang memiliki sifat random untuk semua unit cross-section. Keuntungan model yaitu dapat menghilangkan heteroskedastisitas (Wulandari, 2017). Adapun persamaan regresi REM sebagai berikut:

Keterangan:

$$
\text { Yit }=\text { Xit } \beta+\text { Vit }
$$

Vit : $\mathrm{Ci}+\mathrm{Di}+$ eit

$\mathrm{Ci}$ : Asumsinya memiliki sifat independent and identically distributed (iid) normal apabila mean 0 serta variansi $62 \mathrm{c}$ (komponen cross section)

Di : Asumsinya memiliki sifat iid normal apabila mean 0 serta variansi $62 \mathrm{~d}$ (komponen time series error).

cit : Asumsinya memiliki sifat iid apabila mean 0 dan variansi $62 \mathrm{e}$.

\section{c. Tahapan Analisis Data}

Model dipilih dengan pertimbangan yang paling sesuai dan tepat dengan tujuan penelitian. Berdasarkan karakteristik data yang dimiliki, terdapat tiga uji alat pemilihan model regersi dari data panel meliputi:

1) F Test (Chow Test)

Pemilihan metode Common Effect atau Fixed Effect dilakukan menggunakan uji chow (Munandar, 2017). Adapun saat pengambilan keputusan terdapat ketentuan metode meliputi:

H0 : Common effect

H1 : Fixed effect

Apabila nilai p-value cross section Chi Square < cross section Chi Square $<\alpha=5 \%$ atau probabilitas (p-value) $\mathrm{F}$ test $<\alpha=5 \%$ berarti $\mathrm{HO}$ ditolak atau bisa fixed effect adalah metode yang digunakan. Apabila nilai $p$-value cross section Chi Square $\geq \alpha=5 \%$, atau probabilitas (p-value) $\mathrm{F}$ test $\geq \alpha=5 \%$ berarti H0 diterima, atau common effect sebagai metode yang digunakan.

a) Hausman Test

Fungsi Hausman test adalah sebagai pemilih metode Fixed Effect dan Random Effect lebih bagus daripada Common Effect (Munandar, 2017). Adapun saat pengambilan keputusan menggunakan ketentuan yang meliputi:

$\mathrm{H} 0:$ Random effect

$\mathrm{H} 1$ : Fixed effect

Apabila nilai $p$-value cross section random $<\alpha=5 \%$ berarti H0 ditolak sehingga metode yang digunakan fixed effect. Namun, apabila nilai $p$-value cross section random $\geq \alpha=5 \%$ berarti $\mathrm{H} 0$ diterima sehingga metode yang digunakan random effect.

b) Lagrange Multiplier (LM) Test

Fungsi uji LM adalah sebagai uji pemilih antara metode random effect atau common effect. Uji signifikansi random 


\section{d. Uji Signifikansi}

effect adalah sebutan biasanya dari LM yang dikembangkan Bruesch-Pagan atas dasar nilai residual metode common effect (Munandar, 2017). Adapun saat pengambilan keputusan menggunakan ketentuan yang meliputi:

$\mathrm{H} 0$ : Common effect

$\mathrm{H} 1$ : Random effect

Apabila nilai $p$-value cross section Chi Square $<\alpha=5 \%$, atau nilai probabilitas (P-value) F test $<\alpha=5 \%$, berarti $\mathrm{H} 0$ ditolak sehingga metode yang dipakai random effect. Jika nilai $p$-value cross section Chi Square $\geq \alpha=5 \%$, atau nilai probabilitas (p-value) $\mathrm{F}$ test $\geq \alpha=5 \%$ berarti H0 diterima, sehingga metode common effect yang digunakan.

Uji signifikansi dalam penelitian ini terdiri menjadi beberapa uji, meliputi:

1) Uji Signfikansi Parameter Individual (Uji Statistik T)

Uji statistik $\mathrm{T}$ menunjukkan pengaruh serta signifikansi pada masing-masing variabel independen (penjelas) terhadap variasi variabel dependen. Tingkat keyakinan uji parsial koefisien regresi memakai uji-t dengan skala keyakinan $95 \%$ secara parsial, sedangkan secara analisis $(\alpha)$ 5\% sebagai tingkat kesalahan. Ketentuan degree of freedom $(\mathrm{df})=\mathrm{n}-\mathrm{k}$, dimana $\mathrm{n}$ sebagai besarnya sampel, $\mathrm{k}$ sebagai jumlah variabel (Khoirudin, 2013). Adapun dasar pengambilan keputusannya yakni:

Apabila t-hitung < t-tabel : H0 diterima sedangkan $\mathrm{H} 1$ ditolak

Apabila t-hitung > t-tabel : HO ditolak sedangkan $\mathrm{H} 1$ diterima

2) Uji Signifikansi Simultan ( Uji Statistik F)

Uji Statistik $F$ berperan sebagai penguji seberapa simultan variabel independen yaitu CAR, BOPO, FDR berpengaruh terhadap variabel dependen (ROA). Tingkat keyakinan Uji ini sebesar $95 \%$ sedangkan ( $\alpha$ ) 5\% tingkat kesalahan. Ketentuan degree of freedom (df1) $=\mathrm{k}-1, \mathrm{df} 2=\mathrm{n}-\mathrm{k}$ (Ramadhany et al., 2016). Adapun dasar pengambilan keputusannya yakni:

Apabila f-hitung < F-tabel : H0 diterima sedangkan $\mathrm{H} 1$ ditolak

Apabila f-hitung > F-tabel : H0 ditolak sedangkan $\mathrm{H} 1$ diterima

3) Uji Koefisien Determinasi (R2)

Uji koefisien determinasi R2 bertujuan sebagai pengukur seberapa jauh model bisa menerangkan variasi variabel independen. Nilai koefisien determinasi antara 0 hingga 1 $(0<\mathrm{R} 2<1)$, kecilnya nilai R2 memiliki arti variabel-variabel independen bisa menjelaskan adanya variasi dari variabel independen dengan memberi hingga seluruh keperluan informasi sebagai prediksi variasi model dependen.

\section{Alat Analisis}

Regresi Linier Berganda sebagai alat analisis untuk mengelola hasil penelitian dengan sistem aplikasi EVIEWS. Sistem EVIEWS merupakan aplikasi pada komputer untuk mengolah data statistik serta data ekonometrika. Masalah-masalah yang berbentuk data panel bisa diselesaikan dengan aplikasi tersebut. Data panel adalah data gabungan dari time series serta cross section, yang mana memiliki beberapa periode dan objek. Analisis digunakan untuk meneliti pengaruh CAR, BOPO, dan FDR terhadap ROA dengan NPF sebagai Variabel Moderasi pada perbankan syariah Indoensia dan Malaysia.

\section{HASIL DAN PEMBAHASAN}

\subsection{Hasil penelitian}

Analisis regresi memiliki tujuan mengetahui hubungan dari variabel CAR, BOPO, FDR terhadap ROA serta NPF menjadi variabel moderasi. Berikut adalah tabel hubungan variabel independen terhadap dependen.

Tabel 4. 12 Tabel Hubungan Variabel Independen terhadap Dependen

\begin{tabular}{|c|c|lc|c|}
\hline No & \multicolumn{1}{|c|}{ Hipotesis } & \multicolumn{1}{|c|}{ Hasil } & Ket \\
\hline 1. & CAR berpengaruh positif terhadap ROA & $\begin{array}{l}\text { CAR berpengaruh negatif serta tidak } \\
\text { signifikan terhadap ROA }\end{array}$ & Ditolak \\
\hline 2. & BOPO berpengaruh negatif terhadap ROA & $\begin{array}{l}\text { BOPO berpengaruh positif serta tidak } \\
\text { signifikan terhadap ROA }\end{array}$ & Ditolak \\
\hline
\end{tabular}


Jurnal Ilmiah Ekonomi Islam, 7(02), 2021, 1060

\begin{tabular}{|c|l|l|c|}
\hline No & \multicolumn{1}{|c|}{ Hipotesis } & \multicolumn{1}{|c|}{ Hasil } & Ket \\
\hline 3. & FDR berpengaruh negatif terhadap ROA & $\begin{array}{l}\text { FDR berpengaruh positif serta tidak signifikan } \\
\text { terhadap ROA }\end{array}$ & Ditolak \\
\hline 4. & $\begin{array}{l}\text { NPF berpengaruh positif dalam } \\
\text { memoderasi CAR terhadap ROA }\end{array}$ & $\begin{array}{l}\text { NPF berpengaruh positif signifikan dalam } \\
\text { memoderasi CAR terhadap ROA }\end{array}$ & Diterima \\
\hline 5. & $\begin{array}{l}\text { NPF berpengaruh negatif dalam } \\
\text { memoderasi BOPO terhadap ROA }\end{array}$ & $\begin{array}{l}\text { NPF berpengaruh negatif serta signifikan } \\
\text { dalam memoderasi BOPO terhadap ROA }\end{array}$ & Diterima \\
\hline 6. & $\begin{array}{l}\text { NPF berpengaruh negatif dalam } \\
\text { memoderasi FDR terhadap ROA }\end{array}$ & $\begin{array}{l}\text { NPF berpengaruh negatif serta signifikan } \\
\text { dalam memoderasi FDR terhadap ROA }\end{array}$ & Diterima \\
\hline
\end{tabular}

Sumber: Output EVIEWS 10, data sekunder diolah 2021

Adapun penjelasan uji hipotesis masing-masing variabel meliputi:

a. Pengaruh CAR terhadap ROA

Variabel CAR koefisien alpha 5\% memiliki Coefficient -0.017006 dengan probabilitas 0.2312 $>0.05$ memiliki arti variabel CAR berpengaruh negatif serta tidak signifikan terhadap ROA. Sehingga hipotesis pertama yaitu CAR berpengaruh positif signifikan ditolak.

Hasil penelitian tidak sejalan dengan hasil penelitian C. Zelin (2018), Dedy dan Addien (2017), Desi dan Irene (2016), dan Siti (2015) yaitu variabel CAR berpengaruh positif dan signifikan terhadap ROA. Penyebab CAR tidak signifikan yaitu terdapat aturan wajib dari BI bahwa bank menjaga CAR minimal 8\%. Sehingga perlu menyediakan dana cadangan bank sebagai pemenuhan ketentuan tersebut, selain itu juga untuk mengantisispasi terhadap risiko kredit.

Beberapa penyebab variabel CAR tidak signifikan, meliputi: a) Tingginya modal apabila belum dibarengi dengan tingginya kepercayaan masyarakat, maka tidak ada dampak terhadap profitabilitas. b) Kecenderungan bank dalam investasi dana secara hati-hati dan sangat survival terhadap bank, mengakibatkan CAR tidak memiliki banyak pengaruh terhadap profitabilitas bank. c) Bank tidak mampu menutupi aktiva yang menurun (kerugian bank) akibat adanya aktiva berisiko (surat berharga, penyertaan, kredit, tagihan terhadap bank lain) sehingga pengaruh terhadap profitabilitas kecil (Pinasti \& Mustikawati, 2018). Hasil penelitian sejalur pada penelitian terdahulu oleh Retna Atika Sari (2017).

b. Pengaruh BOPO terhadap ROA

Variabel BOPO koefisien alpha 5\% memiliki Coefficient $=0.007454$ dengan probabilitas $0.2312>0.05$ artinya variabel BOPO berpengaruh positif serta tidak signifikan terhadap
ROA. Sehingga hipotesis kedua yang menyatakan "BOPO berpengaruh negatif serta signifikan" ditolak.

Hasil penelitian tidak sejalan dengan penelitian Dyah (2019), Yani (2017), Monica dkk (2017), dan Ayu (2016) yaitu variabel BOPO berpengaruh negatif serta signifikan terhadap ROA. Hasil penelitian menunjukkan BOPO tidak berpengaruh signifikan terhadap ROA. BI memberi ketetapan angka terbaik rasio BOPO di bawah $85 \%$. Apabila lebih dari angka tersebut, bank termasuk ke dalam kategori tidak efisien pada kegiatan operasionalnya (Pinasti \& Mustikawati, 2018). Hasil penelitian sejalur penelitian oleh Siti (2018) yaitu BOPO tidak berpengaruh terhadap ROA.

c. Pengaruh FDR terhadap ROA

Variabel FDR koefisien alpha 5\% memiliki Coefficient $=0.015195$ serta probabilitas $0.3278>$ 0.05 berarti variabel FDR terdapat pengaruh positif serta tidak signifikan terhadap ROA. Sehingga hipotesis ketiga bahwa "FDR berpengaruh negatif dan signifikan" ditolak. Hasil penelitian tidak sejalan dengan penelitian Kustiyani (2019), Muhammad (2019), Yuwita (2018), Yulia (2017), serta Ridhlo dan Widyarti (2015) yang menunjukkan bahwa FDR berpengaruh negatif serta signifikan terhadap ROA.

Penyaluran kredit berjumlah tinggi memiliki potensi bertambahnya jumlah kredit macet sehingga mengakibatkan laba menurun yang berdampak pada penurunan laba. Sebaliknya, apabila penyaluran kredit secara efektif dan efisien maka laba bank akan meningkat. Dampak dari penyaluran kredit yang tidak efektif tersebut yang menyebabkan risiko semakin tinggi. Hal tersebut mengakibatkan FDR tidak signifikan 


\section{Jurnal Ilmiah Ekonomi Islam, 7(02), 2021, 1061}

terhadap ROA. Hasil penelitian sejalur penelitian oleh Uswatun (2017).

d. Pengaruh CAR terhadap ROA dengan dimoderasi NPF

Variabel FDR dengan koefisien alpha 5\% memiliki Coefficient $=0.010508$ dengan probabilitas $0.0465<0.05$ memiliki arti variabel NPF berpengaruh positif serta signifikan dalam memoderasi CAR terhadap ROA. Sehingga hipotesis keempat yaitu "NPF berpengaruh positif serta signifikan dalam memoderasi CAR terhadap ROA" diterima.

e. Pengaruh BOPO terhadap ROA dengan dimoderasi NPF

Variabel FDR koefisien alpha 5\% memiliki nilai Coefficient $=-0.010931$ serta probabilitas $0.0003<0.05$ memilki arti variabel NPF berpengaruh negatif serta signifikan terhadap ROA. Maka hipotesis kelima yaitu "NPF berpengaruh negatif serta signifikan dalam memoderasi BOPO terhadap ROA" diterima.

f. Pengaruh FDR terhadap ROA dengan dimoderasi NPF

Variabel FDR koefisien alpha 5\% dengan Coefficient $=-0.005008$ serta probabilitas 0.0368 $>0.05$ memiliki arti variabel NPF berpengaruh negatif serta signifikan terhadap ROA. Sehingga hipotesis keenam bahwa "NPF berpengaruh negatif serta signifikan dalam memoderasi FDR terhadap ROA" diterima.

\subsection{Pembahasan}

\section{Analisis Data}

Teknik analisis data yaitu cara olah data terkumpul sehingga bisa memberikan hasil pengolahan data. Tujuan teknik analisis adalah sebagai penjawab dari permasalahan yang dirumuskan. Terdapat beberapa bagian dalam analisis data penelitian meliputi:

\section{a. Statistik Deskriptif Variabel}

Statistik deskriptif sebagai pemberi gambaran data dalam penelitian secara statistik. Statistik deskriptif mengacu terhadap mean (nilai rata-rata), nilai minimum, standar deviation (simpangan baku), dan nilai maksimum semua variabel meliputi ROA, CAR, BOPO, dan FDR, serta NPF periode 2014-2019 sebagaimana ditunjukkan dalam tabel:
Tabel 4.1 Descriptive Statistic

\begin{tabular}{llllll|} 
& BOPO & CAR & FDR & NPF & ROA \\
\hline Mean & 77.19491 & 20.31046 & 88.08676 & 1.282222 & 0.864574 \\
Median & 87.48000 & 18.54500 & 90.73000 & 0.800000 & 0.885000 \\
Maximum & 143.3100 & 54.91000 & 104.7500 & 6.930000 & 5.240000 \\
Minimum & 22.49000 & 10.03000 & 71.87000 & 0.010000 & -2.360000 \\
Std. Dev & 22.71006 & 7.909697 & 7.414968 & 1.442461 & 0.871701 \\
\hline Observation 108 & 108 & 108 & 108 & 108 \\
s & & & & & \\
Sumber: & Output & EVIEWS & 10, data & sekunder & diolah \\
2021 & & & & &
\end{tabular}

Berdasarkan tabel 4.1 banyaknya data pada setiap variabel yaitu 108 buah Bank Syariah Indonesia dan Malaysia meliputi Bank Jabar \& Banten Syariah, Bank BCA Syariah, Bank Rakyat Indonesia Syariah, Bank BNI Syariah, Bank BTPN Syariah, Bank Bukopin Syariah, Bank Syariah Mandiri, Bank Mega Syariah, Bank Muamalat Indonesia, Bank Victoria Syariah, Bank Panin Dubai Syariah, Am Islmaic Bank Berhad, Affin Islamic Bank Berhad, Hong Leong Islamic Bank Berhad, Bank Islam Malaysia Berhad, CIMB Islamic Bank Berhad, Maybank Islmaic Berhad, dan Maybank Islmaic Berhad periode 2014 hingga 2019. Berikut penjabaran masing-masing variabel yang terdapat di dalam data panel:

Variabel profitabilitas diukur dengan ROA. Bank Victoria Syariah memiliki nilai minimum tahun 2015 sebesar $-2,360000$ atau $-2,36 \%$ sedangkan pada Bank BTPN Syariah memiliki nilai maksimum tahun 2015 sebesar 5,240000 atau $5,24 \%$ dan mean sebesar 0,864574 atau $0,86 \%$ hal tersebut memiliki arti sampel perbankan syariah Indonesia dan Malaysia memiliki keadaan cukup sehat berdasarkan Surat Edaran Bank Indonesia No. 13/24/DNDP/2011. Nilai standar deviasi yaitu 0,871701 serta mean sebesar 0,864574 memiliki arti bahwa data kurang bervariasi dikarenakan nilai standar deviasi lebih kecil dari mean.

Variabel CAR pada Am Islmaic Bank Berhad memiliki nilai minimum periode 2015 yaitu 10,03000 atau $10,03 \%$ sedangkan pada BRI Syariah memiliki nilai maksimum periode 2018 yaitu 54,91000 atau $54,91 \%$ dengan mean 20,31046 atau $20,31 \%$ memiliki arti bahwa sampel perbankan syariah penelitian memiliki keadaan sehat berdasarkan Surat Edaran BI No. 13/24/DNDP/2011. Nilai standar deviasi yaitu 
7,909697 serta mean 20,31046 memiliki arti bahwa data bervariasi dikarenakan nilai standar deviasi lebih kecil dari mean.

Variabel BOPO pada RHB Islamic Bank Berhad memiliki nilai minimum periode 2019 yaitu 22,49000 atau $22,49 \%$ sedangkan pada Victoria Syariah memiliki nilai maksimum periode 2014 yaitu 143,3100 atau 143,31\% dengan mean 77,19491 atau 77,19\% memiliki arti bahwa sampel perbankan syariah penelitian memiliki keadaan sehat berdasarkan Surat Edaran BI No. 13/24/DNDP/2011. Nilai standar deviasi yaitu 22,71006 serta mean 77,19491 memiliki arti bahwa data bervariasi dikarenakan nilai standar deviasi lebih kecil dari mean.

Variabel FDR pada BRI Syariah memiliki nilai minimum periode 2017 yaitu 71,87000 atau $71,87 \%$ sedangkan pada Bank Jabar Banten Syariah memiliki nilai maksimum periode 2015 yaitu 104,7500 atau $104,75 \%$ dengan mean 88,08676 atau $88,09 \%$ memiliki arti bahwa sampel perbankan syariah penelitian memiliki keadaan sehat berdasarkan Surat Edaran BI No. 13/24/DNDP/2011. Nilai standar deviasi yaitu 7,414968 serta mean 88,08676 memiliki arti bahwa data bervariasi dikarenakan nilai standar deviasi lebih kecil dari mean.

Variabel NPF pada Am Islmaic Bank Berhad memiliki nilai minimum periode 2017 yaitu 0,010000 atau 0,01\% sedangkan pada Bank Jabar Banten Syariah memiliki nilai maksimum periode 2015 yaitu 6,930000 atau $6,93 \%$ dengan mean 1,282222 atau $1,28 \%$ memiliki arti bahwa sampel perbankan syariah penelitian memiliki keadaan sehat berdasarkan Surat Edaran BI No. 13/24/DNDP/2011. Nilai standar deviasi yaitu 1,442461 serta mean 1,282222 memiliki arti bahwa data kurang bervariasi dikarenakan nilai standar deviasi lebih kecil dari mean.

\section{b. Uji Stasioner}

Uji Stasioneritas bertujuan sebagai penguji data Time Series serta Cross Section supaya tidak terdapat komponen trend, memiliki sifat flat, keragaman konstan serta tidak terdapat fluktuasi periodik (Wulandari, 2017). Unit Root yaitu uji Levin, Linand Chu (LLC) digunakan dalam Uji stasioner penelitian ini. Mengacu kepada data yang diambil dari annual report perbankan syariah Indonesia dan Malaysia tahun 2014-2019 dalam uji tingkat level. Hasil uji stasioner penelitian ini adalah:

Tabel 4.2 Uji Tingkat Level

\begin{tabular}{|c|l|r|c|c|}
\hline No & Variabel & Prob & Keterangan & Posisi \\
\hline 1. & ROA & 0.0000 & Data Stasioner & Level \\
\hline 2. & CAR & 0.0000 & Data Stasioner & Level \\
\hline 3. & BOPO & 0.0000 & Data Stasioner & Level \\
\hline 4. & FDR & 0.0000 & Data Stasioner & Level \\
\hline 5. & NPF & 0.0000 & Data Stasioner & Level \\
\hline
\end{tabular}

Berdasarkan tabel 4.2 memiliki arti bahwa nilai probabilitas $<0.05$ berarti seluruh variabel stasioner. Artinya seluruh data hasil uji tiap variabel dalam penelitian layak dilakukan uji berikutnya.

\section{c. Pemilihan Model Regresi Data Panel}

Tiga model dalam Regresi data panel meliputi CEM, FEM, serta REM. Terdapat keunggulan dan kekurangan pada setiap model. Model yang dipilih didasarkan asumsi yang digunakan oleh peneliti. Peneliti menggunakan signifikansi $5 \%$ serta pengolahan data statistik sesuai syarat yang benar sehingga secara statistik bisa dipertanggungjawabkan. Memilih salah satu dari ketiga model merupakan langkah pertama peneliti lakukan. Hasil regresi model penelitian meliputi:

1) Common Effect Model (CEM)

Olah data pada metode CEM tidak membedakan waktu ataupun tempat penelitian. Asumsinya adalah data setiap unit cross section dalam berbagai kurun waktu yaitu sama (Wulandari, 2017). Berikut hasil dari metode CEM:

Tabel 4.3 Common Effect Model Perbankan Syariah

\begin{tabular}{lllll}
\hline Variabel & Coefficient & $\begin{array}{c}\text { Std. } \\
\text { Error }\end{array}$ & t-Statistic Prob. \\
\hline $\mathrm{C}$ & -1.467327 & 1.007868 & -1.4558730 .1486 \\
CAR & 0.005081 & 0.010526 & 0.482699 & 0.6304 \\
BOPO & 0.004270 & 0.005719 & 0.746702 & 0.4570 \\
FDR & 0.022390 & 0.010731 & 2.086501 & 0.0395 \\
NPF & 1.295056 & 0.229697 & 5.638099 & 0.0000 \\
CARNPF & 0.005296 & 0.003800 & 1.393920 & 0.1664 \\
BOPONPF & -0.009859 & 0.002950 & -3.3402200 .0012 \\
FDRNPF & -0.006589 & 0.001983 & -3.3223150 .0012 \\
\hline
\end{tabular}

Sumber: Output EVIEWS 10, data sekunder diolah 2021 


\section{Jurnal Ilmiah Ekonomi Islam, 7(02), 2021, 1063}

Bentuk model CEM berdasarkan hasil tabel 4.3 adalah: $\mathrm{ROA}=-1.467327+$ $0.005081 \mathrm{CAR}+0.004270 \mathrm{BOPO}+$ $0.022390 \mathrm{FDR}+1.295056 \mathrm{NPF}+$ $0.005296 \mathrm{CARNPF}-0.009854 \mathrm{BOPONPF}-$ 0.006589FDRNPF.

2) Fixed Affect Model (FEM)

Fixed Affect Model (FEM) diasumsikan sebagai data perpaduan yang ada mempunyai konstanta serta koefisien tetap antara waktu dan periode perbankan (Wulandari, 2017). Berikut hasil uji FEM:

Tabel 4.4 Fixed Effect Model Perbankan Syariah

\begin{tabular}{lllll}
\hline Variabel & Coefficient & $\begin{array}{c}\text { Std. } \\
\text { Error }\end{array}$ & t-Statistic Prob. \\
\hline C & -0.110770 & 1.390415 & -0.0796670 .9367 \\
CAR & -0.026810 & 0.017007 & -1.5764280 .1187 \\
BOPO & 0.012944 & 0.004388 & 2.950185 & 0.0041 \\
FDR & 0.005733 & 0.014279 & 0.401512 & 0.6891 \\
NPF & 1.086571 & 0.391858 & 2.772869 & 0.0069 \\
CARNPF & 0.010310 & 0.008203 & 1.256930 & 0.2123 \\
BOPONPF & -0.011864 & 0.003330 & -3.5632250 .0006 \\
FDRNPF & -0.002507 & 0.002735 & -0.9165940 .3620 \\
\hline
\end{tabular}

Sumber: Output EVIEWS 10, data sekunder diolah 2021

Bentuk model FEM berdasarkan hasil tabel 4.4 adalah: ROA $=-0.110770-$ $0.026810 \mathrm{CAR}+0.012944 \mathrm{BOPO}+$ $0.005733 \mathrm{FDR}+1.086571 \mathrm{NPF}+$ $0.010310 \mathrm{CARNPF}-0.011864 \mathrm{BOPONPF}-$ 0.002507FDRNPF.

3) Uji Random Effect Model (REM)

Uji random menggunakan residual dengan dugaan terdapat hubungan antar objek dan waktu (Wulandari, 2017). Berikut hasil uji REM:

Tabel 4.5 Random Effect Model Perbankan Syariah

\begin{tabular}{lllll}
\hline Variabel & Coefficient & \multicolumn{1}{c}{$\begin{array}{c}\text { Std. } \\
\text { Error }\end{array}$} & t-Statistic Prob. \\
\hline C & -0.691603 & 1.390375 & -0.4974220 .6200 \\
CAR & -0.017006 & 0.014117 & -1.2046450 .2312 \\
BOPO & 0.007454 & 0.007327 & 1.017251 & 0.3115 \\
FDR & 0.015195 & 0.015452 & 0.983356 & 0.3278 \\
NPF & 1.201727 & 0.358089 & 3.355945 & 0.0011 \\
CARNPF & 0.010508 & 0.005212 & 2.016043 & 0.0465 \\
BOPONPF & -0.010931 & 0.002917 & -3.7478720 .0003 \\
FDRNPF & -0.005008 & 0.002367 & -2.1161410 .0368 \\
\hline
\end{tabular}

Sumber: Output EVIEWS 10, data sekunder diolah 2021
Bentuk model REM berdasarkan hasil tabel 4.5 adalah: $\mathrm{ROA}=-0.691603-$ $0.017006 \mathrm{CAR}+0.007454 \mathrm{BOPO}+$ $0.015195 \mathrm{FDR}+1.201727 \mathrm{NPF}+$ $0.0105085 \mathrm{CARNPF}-0.010931 \mathrm{BOPONPF}-$ 0.005008 FDRNPF.

\section{d. Pemilihan Model}

Terdapat beberapa uji dalam pemilihan model penelitian, diantaranya meliputi:

1) Uji Chow

Pemilihan metode CEM atau FEM dilakukan menggunakan uji chow (Munandar, 2017). Berikut uji chow penelitian:

Tabel 4.6 Uji Chow Perbankan Syariah

\begin{tabular}{llll}
\hline Effect Tprob.est & Statistic & d.f. & Prob. \\
\hline Cross-section F & 4.387489 & $(17,83)$ & 0.0000 \\
Cross-section Chi-square 69.243014 & 17 & 0.0000 \\
\hline
\end{tabular}

Sumber: Output EVIEWS 10, data sekunder diolah 2021

Nilai cross section Chi-square berdasarkan tabel 4.6 sebesar 69.243014 dengan probabilitas $0.0000<0.05$ dapat diartikan CEM terpilih sehingga perlu melakukan uji selanjutnya yaitu hausman test.

2) Uji Hausman

Fungsi uji Hausman adalah untuk memilih apakah metode FEM dan REM lebih baik daripada metode CEM (Munandar, 2017). Berikut uji hausman penelitian:

Tabel 4.7 Uji Hausman Perbankan Syariah

Test Summary $\quad$ Statistic Chi-Sq. d.f. Prob.

\begin{tabular}{lll}
\hline Cross-section random 8.392681 & 7 & 1.0000
\end{tabular}

Sumber: Output EVIEWS 10, data sekunder diolah 2021

Nilai cross section random pada tabel 4.7 yaitu 8.392681 dan probabilitas $1.0000>0.05$ diartikan REM terpilih maka perlu melakukan uji selanjutnya yaitu lagrange multiplier.

3) Uji Lagrange Multiplier

Fungsi uji LM adalah untuk memilih antara metode REM atau CEM. Berikut uji Lagrange Multiplier penelitian: 
Jurnal Ilmiah Ekonomi Islam, 7(02), 2021, 1064

Tabel 4.8 Uji Lagrange Multiplier Perbankan Syariah

\begin{tabular}{|c|c|c|c|}
\hline \multicolumn{4}{|c|}{ Syariah } \\
\hline & $\begin{array}{l}\text { Cross- } \\
\text { section }\end{array}$ & $\begin{array}{l}\text { Test } \\
\text { Hypothesis } \\
\text { Time }\end{array}$ & Both \\
\hline Breusch-Pagan & $\begin{array}{l}20.27443 \\
(0.0000)\end{array}$ & $\begin{array}{l}1.801243 \\
(0.1796)\end{array}$ & $\begin{array}{l}22.07567 \\
(0.0000)\end{array}$ \\
\hline Honda & $\begin{array}{l}4.502713 \\
(0.0000)\end{array}$ & $\begin{array}{l}1.342104 \\
(0.0898)\end{array}$ & $\begin{array}{l}4.132910 \\
(0.0000)\end{array}$ \\
\hline King-Wu & $\begin{array}{l}4.502713 \\
(0.0000)\end{array}$ & $\begin{array}{l}1.32104 \\
(0.0353)\end{array}$ & $\begin{array}{l}3.326360 \\
(0.0004)\end{array}$ \\
\hline Standardized Honda & $\begin{array}{l}5.603171 \\
(0.0000)\end{array}$ & $\begin{array}{l}1.808512 \\
(0.0353)\end{array}$ & $\begin{array}{l}1.323745 \\
(0.0928)\end{array}$ \\
\hline $\begin{array}{l}\text { Standardizad King } \\
\text { Wu }\end{array}$ & $\begin{array}{c}-5.603171 \\
(0.0000)\end{array}$ & $\begin{array}{l}1.808512 \\
(0.0353)\end{array}$ & $\begin{array}{l}0.821107 \\
(0.0928)\end{array}$ \\
\hline Gourierioux, et al.* & -- & -- & $\begin{array}{l}22.07567 \\
(<0,01)\end{array}$ \\
\hline
\end{tabular}

Sumber: Output EVIEWS 10, data sekunder diolah 2021

Nilai Both pada tabel 4.8 yaitu 22.07567 probabilitas $0.0000<0.05$ diartikan REM terpilih sebagai model penelitian.

\section{e. Uji Kebaikan Model}

Terdapat beberapa uji kebaikan model penelitian, diantaranya sebagai berikut:

1) Koefisien Determinasi $\left(\mathbf{R}^{2}\right)$

Koefisien determinasi R2 menunjukkan tingkat model regresi mampu menerangkan variabel-variabel independen mempengaruhi variabel dependen. Berikut uji koefisien determinasi Perbankan Syariah:

Tabel 4.9 Tabel Koefisien Determinasi

Perbankan Syariah

\begin{tabular}{|l|l|l|l|}
\hline R-squared & 0.230831 & Mean dependent var & 0.381662 \\
\hline $\begin{array}{l}\text { Adjusted } \\
\text { R-squared }\end{array}$ & 0.176990 & S.D. dependent var & 0.687499 \\
\hline $\begin{array}{l}\text { S.E. of } \\
\text { regression }\end{array}$ & 0.623699 & Sum squared resid & 38.90004 \\
\hline $\begin{array}{l}\text { F-statistic } \\
\text { Prob (F-287217 }\end{array}$ & Durbin-Watson start & 1.169844 \\
\hline $\begin{array}{l}\text { Prob } \\
\text { statistic) }\end{array}$ & & & \\
\hline
\end{tabular}

Sumber: Output EVIEWS 10, data sekunder diolah 2021

Angka R-squared pada tabel 4.9 sebesar 0.230831 . Pengaruh variabel independen terhadap variabel dependen yaitu $23.08 \%$ atau dengan kata lain variabel independen yang dipakai pada model dapat menjelaskan yaitu $23.08 \%$ terhadap variabel dependen. Sisanya
$76.92 \%$ dipengaruhi faktor lain dari model regresi tersebut.

2) Uji F (Simultan)

Uji Statistik F memiliki tujuan dalam uji secara simultan variabel independen yaing terdiri dari CAR, BOPO, dan FDR berpengaruh terhadap variabel dependen yaitu ROA dengan dimoderasi NPF. Jika nilai Probabilitas $(F$-statistic $)<0.05$ berarti variabel independen secara simultan berpengaruh signifikan terhadap variabel dependen, begitu sebaliknya (Ramadhany et al., 2016). Berikut hasil uji F penelitian:

Tabel 4.10 Uji F Perbankan Syariah

\begin{tabular}{|l|l|l|l|}
\hline R-squared & 0.230831 & $\begin{array}{l}\text { Mean } \\
\text { dependent } \\
\text { var }\end{array}$ & 0.381662 \\
\hline $\begin{array}{l}\text { Adjusted } \\
\text { R-squared }\end{array}$ & 0.176990 & $\begin{array}{l}\text { S.D. } \\
\text { dependent } \\
\text { var }\end{array}$ & 0.687499 \\
\hline $\begin{array}{l}\text { S.E. of } 0.623699 \\
\text { regression }\end{array}$ & $\begin{array}{l}\text { Sum } \\
\text { squared } \\
\text { resid }\end{array}$ & 38.90004 \\
\hline $\begin{array}{l}\text { F-statistic } \\
\text { 4.287217 }\end{array}$ & $\begin{array}{l}\text { Durbin- } \\
\text { Watson start }\end{array}$ & 1.169844 \\
\hline $\begin{array}{l}\text { Prob (F-0.000350 } \\
\text { statistic) }\end{array}$ & & \\
\hline
\end{tabular}

Sumber: Output EVIEWS 10, data sekunder diolah 2021

Koefisiensi penelitian berdasarkan tabel 4.10 yaitu 4.287217 dengan nilai Probabilitas (Fstatistic) $0.000350<0.05$ berarti variabel independen secara simultan berengaruh positif dan signifikan terhadap ROA.

\section{f. Uji Asumsi}

Model yang terpilih adalam REM sehingga tidak dilakukan uji asumsi kalsik karena REM sebagai metode estimasi generalized least square (GLS). Teknik GLS dipercaya mengatasi adanya autokorelasi runtun waktu (time series) dan korelasi antar observasi (cross section). Metode GLS menghasilkan estimator yang bertujuan memenuhi sifat best linier unbiased estimation (BLUE) sebagai metode treatment untuk mengatasi pelanggaran asumsi homoskedastisitas dan autokorelasi (Kosmaryati et al., 2019).

g. Uji Statistik

Uji signifikansi dalam penelitian ini terdiri menjadi beberapa uji, meliputi:

Signifikansi Parameter Individual (Uji t) 


\section{Jurnal Ilmiah Ekonomi Islam, 7(02), 2021, 1065}

Uji $\mathrm{t}$ dalam penelitian bertujuan untuk menguji koefisien regresi secara individual signifikansi variabel independen terhadap variable dependen dengan asumsi variabel independen lainnya dianggap konstan untuk kepercayaan 5\% (Ghozali, 2020). Jika nilai prob $<0.05$ memiliki arti signifikan yaitu ada pengaruh variabel independen secara individual terhadap variabel dependen. Uji t penelitian meliputi:

Tabel 4.11 Uji t Perbankan Syariah

Variabel Coefficient Std. Error t-Statistic Prob.

$\begin{array}{lllll}\text { C } & -0.691603 & 1.390375 & -0.497422 & 0.6200 \\ \text { CAR } & -0.017006 & 0.014117 & -1.204645 & 0.2312 \\ \text { BOPO } & 0.007454 & 0.007327 & 1.017251 & 0.3115 \\ & & & & \\ \text { FDR } & 0.015195 & 0.015452 & 0.983356 & 0.3278 \\ \text { NPF } & 1.201727 & 0.358089 & 3.355945 & 0.0011 \\ \text { CARNPF } & 0.010508 & 0.005212 & 2.016043 & 0.0465 \\ \text { BOPONPF } & -0.010931 & 0.002917 & -3.747872 & 0.0003 \\ \text { FDRNPF } & -0.005008 & 0.002367 & -2.116141 & 0.0368\end{array}$

Sumber: Output EVIEWS 10, data sekunder diolah 2021

UJi t perbankan syariah yang terdapat dalam tabel 4.11 yakni:

1) Pengaruh CAR terhadap ROA

Variabel CAR dengan koefisien alpha 5\% bernilai Coefficient $=-0.017006$ dengan probabilitas $0.2312>0.05$ memiliki arti CAR berpengaruh negatif serta tidak signifikan terhadap ROA.

2) Pengaruh BOPO terhadap ROA

Variabel BOPO dengan koefisien alpha 5\% bernilai Coefficient $=0.007454$ dengan probabilitas $0.2312>0.05$ memiliki arti BOPO berpengaruh positif serta tidak signifikan terhadap ROA.

3) Pengaruh FDR terhadap ROA

Variabel FDR dengan koefisien alpha 5\% bernilai Coefficient $=0.015195$ dengan probabilitas $0.3278>0.05$ memiliki arti FDR berpengaruh positif serta tidak signifikan terhadap ROA.

4) Pengaruh CAR terhadap ROA dengan NPF sebagai Variabel Moderasi

Variabel FDR dengan koefisien alpha 5\% bernilai Coefficient $=0.010508$ dengan probabilitas $0.0465<0.05$ memiliki arti variabel NPF berpengaruh positif serta signifikan dalam memoderasi CAR terhadap ROA.

5) Pengaruh BOPO terhadap ROA dengan NPF sebagai Variabel Moderasi

Variabel FDR dengan koefisien alpha 5\% bernilai Coefficient $=-0.010931$ dengan probabilitas $0.0003<0.05$ memiliki arti variabel NPF berpengaruh negatif serta signifikan terhadap ROA.

6) Pengaruh FDR terhadap ROA dengan NPF sebagai variabel Moderasi

Variabel FDR dengan koefisien alpha 5\% bernilai Coefficient $=-0.005008$ dengan probabilitas $0.0368>0.05$ memiliki arti variabel NPF berpengaruh negatif serta signifikan terhadap ROA.

\section{KESIMPULAN}

Mengacu pada hasil penelitian yang telah dilakukan tentang faktor-faktor yang mempengaruhi profitabilitas bank syariah Indonesia dan Malaysia periode 2014-2019 sehingga diambil kesimpulan meliputi:

a. CAR berpengaruh negatif serta tidak signifikan terhadap profitabilitas (ROA). Memiliki arti jika CAR turun tidak akan berpengaruh terhadap profitabilitas.

b. BOPO berpengaruh positif serta tidak signifikan terhadap ROA. Memiliki arti jika BOPO naik tidak akan berpengaruh terhadap profitabilitas.

c. FDR berpengaruh positif serta tidak signifikan terhadap ROA. Memiliki arti jika nilai FDR naik tidak akan berpengaruh terhadap profitabilitas.

d. NPF berpengaruh positif serta signifikan dalam memoderasi CAR terhadap ROA. Memiliki arti jika nilai FDR yang dimoderasi oleh NPF naik maka akan menaikkan profitabilitas.

e. NPF berpengaruh negatif serta signifikan dalam memoderasi BOPO terhadap ROA. Memiliki arti jika nilai BOPO yang dimoderasi NPF turun maka akan menaikkan profitabilitas.

f. NPF berpengaruh negatif serta signifikan dalam memoderasi FDR terhadap ROA. Memiliki arti jika nilai FDR yang dimoderasi oleh NPF turun maka akan menaikkan profitabilitas. 


\section{DAFTAR PUSTAKA}

Abdullah, M. Y., Noor, M. M., Mohamad, M. T., Shahruddin, M. S., Zaini, M. N. M., \& Paidi, M. (2019). TANGGUNGJAWAB SOSIAL KORPORAT (CSR): PENGLIBATAN INSTITUSI PERBANKAN BERASASKAN ISLAM TERPILIH DI MALAYSIA DALAM INDUSTRI WAKAF. Social Finance, 10.

Almunawwaroh, M., \& Marliana, R. (2018). PENGARUH CAR,NPF DAN FDR TERHADAP PROFITABILITAS BANK SYARIAH DI INDONESIA. Amwaluna: Jurnal Ekonomi dan Keuangan Syariah, 2(1), 1-17. https://doi.org/10.29313/amwaluna.v2i1.3156

Anam, M. S., Inawati, Y., \& Rosia, R. (2021). FACTORS AFFECTING THE HUMAN DEVELOPMENT INDEX (HDI) IN CENTRAL JAVA PROVINCE. 6(1), 11.

Ardana, Y. (2018). Faktor Eksternal dan Internal yang Mempengaruhi Profitabilitas Bank Syariah di Indonesia. Cakrawala, 13(1), 51. https://doi.org/10.31603/cakrawala.v13i1.2042

Arinta, Y. N. (2016). Analisis Perbandingan Kinerja Keuangan antara Bank Syariah dan Bank Konvensional (Studi Kasus pada Bank Syariah Mandiri dan Bank Mandiri). Muqtasid: Jurnal Ekonomi dan Perbankan Syariah, 7(1), 119. https://doi.org/10.18326/muqtasid.v7i1.119-140

Arnova, I. (2016). PENGARUH UKURAN KINERJA ROA, ROE, EPS DAN EVA TERHADAP RETURN SAHAM. EKOMBIS REVIEW: Jurnal Ilmiah Ekonomi dan Bisnis, 4(1). https://doi.org/10.37676/ekombis.v4i1.153

Ghozali, I. (2020). 25 Grand Theory 25 Teori Besar Ilmu Manajemen, Akuntansi, dan Bisnis (1st ed.). YOGA

PRATAMA. http://www.imamghozali.com

Handayani, S., \& Budianingrum, S. (2011). ANALISIS FAKTOR YANG MEMPENGARUHI KEKURANGAN ENERGI KRONIS PADA IBU HAMIL DI WILAYAH PUSKESMAS WEDI KLATEN. 19.

Kabib, N., Hayati, S. N., \& Fatimatuzzahra, S. (2021). Apakah Penerapan Standar Akuntansi, Kompetensi Sumberdaya Manusia serta Peran Auditor Internal mempengaruhi Kualitas Laporan Keuangan? Jurnal Akuntansi dan Pajak, 21(02). https://doi.org/10.29040/jap.v21i02.1335
Khasanah, A. N. (2016). PENGARUH INTELLECTUAL CAPITAL DAN ISLAMICITY PERFORMANCE INDEX TERHADAP KINERJA KEUANGAN PERBANKAN SYARIAH DI INDONESIA. Nominal, Barometer Riset Akuntansi dan Manajemen, $5(1)$. https://doi.org/10.21831/nominal.v5i1.11473

Khoirudin, A. (2013). CORPORATE GOVERNANCE DAN PENGUNGKAPAN ISLAMIC SOCIAL REPORTING PADA PERBANKAN SYARIAH DI INDONESIA. 6.

Komasari, D., \& Helmi, A. F. (2000). FAKTORFAKTOR PENYEBAB PERILAKU MEROKOK PADA REMAJA. 11.

Kosmaryati, K., Handayani, C. A., Isfahani, R. N., \& Widodo, E. (2019). Faktor-Faktor yang Mempengaruhi Kriminalitas di Indonesia Tahun 2011-2016 dengan Regresi Data Panel. Indonesian Journal of Applied Statistics, 2(1), 10. https://doi.org/10.13057/ijas.v2i1.27932

Marimin, A., \& Romdhoni, A. H. (2017). PERKEMBANGAN BANK SYARIAH DI INDONESIA. Jurnal Ilmiah Ekonomi Islam, 1(02). https://doi.org/10.29040/jiei.v1i02.30

Mulyadi, M. (2013). PENELITIAN KUANTITATIF DAN KUALITATIF SERTA PEMIKIRAN DASAR MENGGABUNGKANNYA. Jurnal Studi Komunikasi dan Media, 15(1), 128. https://doi.org/10.31445/jskm.2011.150106

Munandar, A. (2017). ANALISIS REGRESI DATA PANEL PADA PERTUMBUHAN EKONOMI DI NEGARA - NEGARA ASIA. 8, 9.

Munifa, M., Bombang, S., \& Sofyan, S. (2019). Strategi Penyelesaian Pembiayaan Bermasalah Pada Transaksi Murabahah Pada PT. Bank Muamalat Indonesia (BMI) Cabang Palu dalam Perspektif Ekonomi Syariah. Jurnal Ilmu Perbankan dan Keuangan Syariah, 1(1), 73-95. https://doi.org/10.24239/jipsya.v1i1.6.73-95

Munir, M. (2018). Analisis Pengaruh CAR, NPF, FDR dan Inflasi terhadap Profitabilitas Perbankan Syariah di Indonesia. Ihtifaz: Journal of Islamic Economics, Finance, and Banking, 1(1), 89. https://doi.org/10.12928/ijiefb.v1i1.285

Novalia, F., \& Nindito, M. (2016). PENGARUH KONSERVATISME AKUNTANSI DAN ECONOMIC VALUE ADDED TERHADAP PENILAIAN EKUITAS PERUSAHAAN. 11, 17. 
Nuryanto, R., Tho'in, M., \& Wardani, H. K. (2014). Rasio Likuiditas, Rasio Solvabilitas, Rasio Rentabilitas Koperasi Jasa Keuangan Syariah Di Jawa Tengah. Jurnal Akuntansi dan Pajak, 15(01).

Pinasti, W. F., \& Mustikawati, RR. I. (2018). PENGARUH CAR, BOPO, NPL, NIM DAN LDR TERHADAP PROFITABILITAS BANK UMUM PERIODE 2011-2015. Nominal, Barometer Riset Akuntansi dan Manajemen, $7(1)$.

https://doi.org/10.21831/nominal.v7i1.19365

Pravasanti, Y. A. (2018). Pengaruh NPF dan FDR Terhadap CAR dan Dampaknya Terhadap ROA Pada Perbankan Syariah Di Indonesia. Jurnal Ilmiah Ekonomi Islam, 4(03), 148. https://doi.org/10.29040/jiei.v4i03.302

Ramadhany, R., Aminah, M., \& Permanasari, Y. (2016). Analisis Faktor yang Mempengaruhi Kebijakan Hutang Emiten Pertanian di Bursa Efek Indonesia. Jurnal Manajemen dan $\begin{array}{lll}\text { Organisasi, } & 6(3), & \end{array}$ https://doi.org/10.29244/jmo.v6i3.12611

Rifai, M., Arifati, R., \& Si, M. (2013). PENGARUH UKURAN PERUSAHAAN, STRUKTUR MODAL DAN PERTUMBUHAN PERUSAHAAN TERHADAP PROFITABILITAS STUDI PADA PERUSAHAAN MANUFAKTUR DI BEI TAHUN 2010-2012. 8.

Sambelay, J. J., \& Rate, P. V. (2017). ANALISIS PENGARUH PROFITABILITAS TERHADAP HARGA SAHAM PADA PERUSAHAAN YANG TERDAFTAR DI LQ45 PERIODE 2012-2016. 9.

Sengkey, J. I. B., Murni, S., \& Tulung, J. E. (2018). ANALISIS FAKTOR - FAKTOR YANG MEMPENGARUHI RISIKO LIKUIDITAS BANK (STUDI KASUS PADA BANK UMUM SWASTA NASIONAL YANG TERDAFTAR DI BEI PERIODE 2012-2015). 10.
Siagian, T. S., Khair, H., \& Pascasarjana Universitas Muhammadiyah Sumatera Utara. (2018). Pengaruh Gaya Kepemimpinan Dan Lingkungan Kerja Terhadap Kinerja Karyawan Dengan Kepuasan Kerja Sebagai Variabel Intervening. Maneggio: Jurnal Ilmiah Magister Manajemen, l(1), 59-70. https://doi.org/10.30596/maneggio.v1i1.2241

Tho'in, M. (2019). Profitability of Islamic Commercial Banks in Indonesia. IQTISHADIA: Jurnal Ekonomi dan Perbankan Syariah, 6(2), 89-99.

Wibisono, M. Y. (2017). PENGARUH CAR, NPF, BOPO, FDR, TERHADAP ROA YANG DIMEDIASI OLEH NOM. 17(1), 22.

Wiwoho, J. (2014). PERAN LEMBAGA KEUANGAN BANK DAN LEMBAGA KEUANGAN BUKAN BANK DALAM MEMBERIKAN DISTRIBUSI KEADILAN BAGI MASYARAKAT. $1,11$.

Wulandari, N. (2017). Analisis Faktor-Faktor yang Mempengaruhi Inflasi pada Kota Metropolitan di Indonesia dengan Menggunakan Analisis Data Panel. 3(2), 9.

Yuliana, R. (2012). ANALISIS PENGARUH STRATEGI SERVICE RECOVERY YANG DILAKUKAN PERBANKAN TERHADAP KEPUASAN NASABAH DI KOTA SEMARANG. 4(2), 14.

Zulifiah, F., \& Susilowibowo, J. (2014). PENGARUH INFLASI, BI RATE, CAPITAL ADEQUACY RATIO (CAR), NON PERFORMING FINANCE (NPF), BIAYA OPERASIONAL DAN PENDAPATAN OPERASIONAL (BOPO) TERHADAP PROFITABILITAS BANK UMUM SYARIAH PERIODE 20082012. Jurnal Ilmu Manajemen, 2, 12. 